\title{
Paradise Lost Dressed in the Costume of History: John Martin's Rendition of Paradise Lost
}

\author{
Laleh Atashi \\ Alireza Anushiravani \\ Ph.D. Candidate of English Literature, Shiraz University, Shiraz, Iran \\ Associate Professor of Comparative Literature, Shiraz University, Shiraz, Iran \\ e-mails: laleh.atashi@gmail.com \\ anushir@shirazu.ac.ir
}

\begin{abstract}
The story of the loss of paradise has been read and interpreted in different ages. Commentary on Milton's Paradise Lost is not limited to verbal texts; painters and illustrators have contributed greatly to the poem by presenting their own time-bound readings and interpretations of the poem through their illustrations that are far beyond mere decorations. John Martin, in the aftermath of the Industrial Revolution, deletes the Father and the Son from his illustrations. Only angels such as Raphael are the representations of deity and are as powerless and tiny as Adam and Eve. Adam and Eve, after the Fall seem as small, powerless and as subjugated to the natural surrounding as they were before the Fall. Satan is the only powerful figure in his elegant palace. Through a new historical outlook, the researchers aim at exposing the workings of ideology and dominant discourses that informed John Martin's pictorial reading of Milton's poem in the early $19^{\text {th }}$ century.
\end{abstract}

Key words: John Martin, John Milton, Paradise Lost, illustrations, new historicism, interdisciplinarity

When Foucault put forth the idea of episteme in 1950s and rejected the idea of the progressive movement of history, a new perspective took over in the humanities. He argued that each epoch has its own knowledge system and that each text must be located in its proper context in order to be properly understood. The new perspective replaced the universals with time specific events. As a result, the old notion that human history is moving along a continuum seemed no longer valid. Shifting the point of view to the historical context was the contribution of historicism which held that all questions must be settled within the historical, political, social and economic context in which they have been raised. This school of thought is known by the name of New Historicism. 
One of the tenets of the New Historicism is that literature is not created in a vacuum, it is the product of a historical era and cannot be considered the production of a genius individual who lives beyond and detached from history; instead, literature is considered a construct informed by elements beyond the individual consciousness. Therefore, the best way to understand literature is going through the cultural and historical terms that have phrased it. According to this vision, literature is not distinct from history; both literature and history are considered texts which are in turn, mere constructs. Therefore the two catch phrases, historicity of texts/textuality of history, mean that all texts may be examined for their historicity, just as any historical phenomenon can be analyzed in the same way a literary text can be dissected.

Accordingly, it can be concluded that even human beings, writers, poets and artists, like literature and history, are texts constructed by political, social and historical discourses, hence the rejection of the old humanistic slogan that humanity has a meaning beyond history. The Renaissance man belonged to the Renaissance period and the modern man cannot be considered the Renaissance man after progress! The concept of humanity underwent the same ruptures that history did. An objective underlying structure does not exist in New Historicism. The same concept rules when New Historicism comes to the criticisms produced by the literary critics: critics cannot escape their present time and are actually trapped in it. Therefore, their observation is not an objective truth but a time-bound interpretation. Given this fact, the best a modern historicist approach to literature can hope to accomplish, according to Catherine Belsey (1980), is "to use the text as a basis for the reconstruction of an ideology" (p. 144). The New Historicist concept of textuality is specifically helpful to the researchers in their analysis of John Martin's illustrations of Paradise Lost which are pictorial texts interpreting Milton's poem in the post industrial England.

New Historicism, unlike Formalism, is not after the original meaning but the ideology that informed the text. Ideology, according to Barker (2003), consists of "maps of meaning that while they purport to be universal truths, are historically specific understandings that obscure and maintain power" (p. 10). The goal of New Historicism is not to uncover an experience by interpreting a text, but to examine the way the discourse orients the language of the system in which it functions. Tyson (2006) defines discourse as: 
A social language created by particular cultural conditions at particular time and place, and it expresses a particular way of understanding human experience. Although the word discourse has roughly the same meaning as the word ideology, and the two terms are often used interchangeably, the word discourse draws attention to the role of language as the vehicle of the ideology (p. 285).

The web of discourses at work at the beginning of the $19^{\text {th }}$ century was, consciously or unconsciously, translated into the pictorial representations of Paradise Lost by John Martin. Aligning poetry with painting or text with image has a long history whose aim has been the enhancement of meaning rather than merely decorating the verbal text. To find a proper method of comparison between literature and arts, Gathier refers to Lessing, the $18^{\text {th }}$ century critic, who tried to make distinctions between the nature of the two and discover their differing potentials to affect the audience. He argued that poetry and painting rely upon different techniques and achieve different goals and leave different effects upon the audience: painting depicts a single moment, poetry represents a temporal process. Therefore, painting has the element of space, and poetry has the element of time at its disposal. When we read a poem, our grasp of it depends upon a sequence of effects in time. Therefore, the painter, according to Lessing, should choose to illustrate the most pregnant moment in order to leave the strongest effect on the viewer, but the poet can take his time in his narration of a sequence of events and his development of his idea (as cited in Gaither, 1971, pp. 1567).

In the analysis of illustrated poetry, the signs of painting contribute to the concepts put into words through the poem. The painters act as readers of the poem: negotiate with, interpret, comment on, and criticize it. Nikolajeva (2000), Professor of Comparative Literature at Stockholm University, finds the examination of the word/image interaction, "so rich and so promising in its ability to penetrate and unlock the intricacies" (p. 225) of the concept that is supposed to be transferred to the reader. Paradise Lost has undergone different interpretations through the passage of time. To critics of different ages, painters and illustrators among them, Paradise Lost has offered fresh raw materials with which they could tackle to reach new depths; that is, every period has looked at Paradise Lost through different lenses fashionable at that time. 
Commentary on the poem is not limited to verbal criticism. Painters and engravers have produced ample criticism on the poem through their art. Having haunted the imagination of artists of different times and places, the myth of "paradise lost" has assumed different appearances in the works of different artists. When illustrated, the poem has come up with different versions of itself when read in different social and political milieu in which the painters have lived. Accordingly, particular aspects of the poem are highlighted to emphasize the milieu-bound requirements. The protagonists and antagonists change places, the human figures are subjugated to the paradisal setting in one version and domineering in another; e.g. Eve has a proud erect posture in one scene and tragically broken in another. The artist sometimes emphasizes the power of Satan, sometimes that of the deities and sometimes that of Adam and Eve. All these different versions are made under the influence of the discursive practices of the time during which the artist/interpreter has lived.

The main significance of this research lies in its interdisciplinarity, a major trend in comparative literary studies. It is a new reading of Paradise Lost in the sense that it uses painting to demonstrate the different readings of Paradise Lost and the haunting effect of the poem on the artists of the generations to come.

\section{DISCUSSION}

John Martin (1789-1854) was born in the week that the Bastille was stormed in July 1789. In 1806 John came south to London to make his fortune as an artist. Martin, influenced by the scientific progress of his time, consolidates the ideology of the time which was progress and perfected civilization. Martin liked the company of scientists and engineers. He had been close friends with the scientist and natural philosopher Michael Faraday (1791-1867). John Martin had plans of engineering a water supply and sewage system for the government and Faraday was always his supporter. Martin had always had a passion for architecture and engineering. During his lifetime, he did not have the chance or luck to see his plans adopted, but nearly all of them were carried out by men of the next generation, like Bazalgette and Paxton, when cholera and the Great Stink led to a hygienic crisis in London. Martin also became acquainted with George Stephenson who was an engineer that improved the engine of locomotives and made safety lamps for minors, 
and also with Humphrey Davy, the great chemist and inventor. The ideology of progress and perfected civilization prevalent during the early $19^{\text {th }}$ century is reinforced through the following discourses.

\section{The Discourse of Civilizing Mission}

From about 1780 the achievements of the Industrial Revolution enthroned the machine as the symbol of the west, and consequently, the mastery of nature turned into the criteria against which civilization could be gauged. The idea that technology was the key to civilization was mainly supported by men of modest origins, like James Mill, John Barrow, Gustave Le Bon, whose fathers had humble jobs and had no claims to any inherited wealth. They held that it was Europe's capacity to change and progress by applying the results of each scientific discovery which built its civilization, and contributed to its uniqueness.

Adas, in Machine as the Measure of Man, a survey of the British imperialism before and after the Industrial Revolution, notes that Britain in its pre-industrial Imperialism more than often witnessed its inferiority to the industry of the host country, and therefore the Britons tried to justify their imperialistic pursuits in religious terms: their mission was spreading Christianity. As time went on, the Europeans began to build faster ships, bigger guns, and more complex machines. These new developments shifted their justification, from religious superiority to a moral worth begotten by their industrial progress (Adas, 1989, p. 79). In the eyes of the Europeans, lack of technological or scientific development equaled moral shortcomings: "scientific glory of a country may be considered, in some measure, as an indication of its innate strength" (Davy, 1802, p. 359).

European imperialism during the age of the Industrial Revolution was justified by the "civilizing mission." Europeans saw themselves as having a duty to bring the moral and material benefits of Western civilization to "backward" cultures. Earthly empires, was enthroned and supported by the philosophy of Utilitarianism phrased by Bentham (1823) who defined human disposition and prescribed the measure of human actions as follows: "it will be good or bad according to its effects; according to the effects it has in augmenting or diminishing the happiness of the community" (p. 105). The desire to build Earthly empires and the quest for universal scientific understanding were so closely connected that they were used synonymously. The "civilizing mission" ideology of nineteenth- 
century Europeans centered on the belief that technologically advanced people were obligated to serve as teachers for the less fortunate and backward people of the non-Western world.

\section{The Discourse of Scientific Progress}

After the industrial Revolution, the machines changed the organization of society, and shifted the center of man's life from his cottage home to the daily factory. In the $19^{\text {th }}$ century, as the European agrarian society gave way to an urbanized and industrialized lifestyle, the rising middle class protested that the classical education based on Roman and Greek literature enjoyed by the aristocracy failed to prepare the new professional classes for modern life. If Horace was a must read for the aristocracy in the pre industrial era, to the rising middle class whose life and income were embedded in the industrial and technological society, science became an essential part of the educational curriculum. Science, as the harbinger of progress is exalted by scientists such as Sir Humphrey Davy in his lectures on chemistry in 1802:

science has done much for man, but it is capable of doing still more, its sources of improvement are not yet exhausted; the benefits that it has conferred aught to excite our hopes of its capability of conferring new benefits; and, in considering the progressiveness of our nature, we may reasonably look forward to a state of greater cultivation and happiness than that we at present enjoy (p. 142).

Sir Humphry Davy was vitally concerned to dramatize the importance of science. He pointed to the superiority of Britain in physical science and boasts of Britain's scientific achievements in the previous centuries and tried to draw a progressive continuum along which it was the duty of the Englishmen to move: "Englishmen should assist the heirs of Newton and Bacon in their efforts, so that Britain would not be overtaken in her endeavors" (as cited in Foote, 1954, p. 440). He also believed in the great influence of science and the way it aroused the curiosity of the public and attracted the attention of the artists. He went on to establish a link between the improvements in man's condition and happiness and the progress of science or what he called the experimental arts. 


\section{The Discourse of Struggle for Existence}

When Darwin published Origin of Species in 1859, he shifted the emphasis away from the harmony between man and nature into a combative tension and struggle that have been in progress since the prehistoric times. The notion of struggle had been influential in early $19^{\text {th }}$ century British social sciences ever since the publication of the political economist Thomas Malthus' "Essay on Population". In his essay, he warned against the dangers of population growth that threatened to exhaust food supplies in 1798:

This natural inequality of the two great powers of population and of production in the earth and that great law of our nature which must constantly keep their effects equal form the great difficulty that to me appears insurmountable in the way to the perfectibility of society (as Cited in Bowler, 1976, p. 637).

Darwin acknowledged his debt to Malthus and admitted that he expanded upon Malthus theory of struggle for existence when he articulated his theory of natural selection:

In October, 1838, that is, fifteen months after I had begun my systematic enquiry, I happened to read for amusement 'Malthus on Population,'... and being well prepared to appreciate the struggle for existence which everywhere goes on from long-continued observation of the habits of animals and plants, it at once struck me that under these circumstances favorable variations would tend to be preserved, and unfavorable ones to be destroyed. (as cited in Barlow, 1958, pp. 34-35)

In effect, Darwin's early conception of natural selection was inspired not simply by scientific theories and evidence, but by the new paradigm of competition being popularized by Britain's political economists during the industrial revolution. Therefore, long before Darwin published The Origin of the Species, the idea of struggle for survival was in the air.

\section{John Martin's interpretation of Paradise Lost}

Martin started illustrating Paradise Lost in 1824 and finished the project in 1827. A few of Martin's illustrations are closely read to elucidate 
how supposedly autonomous works of art participate in the labor of elaborating and consolidating the practice of empire by fixing and naturalizing the spatial relations that empower the imperial center.

Martin, influenced by the discourse of struggle for existence, points to the dangers that threaten the existence of Adam and Eve by using animal imagery. The world, in which Adam and Eve should live after eating the fruit, is a setting whose peaceful harmony is broken. Martin depicts this broken harmony in the vignette of lion and deer (Fig. 1). In the distance, the deer is escaping from the chasing lion; this detail, according to Wolf, "is a pre-figuration of a Darwinian mode of competition in a world defined by death and the narrative of survival." In the Expulsion Scene (Fig. 2), Martin integrates the discourses of science and struggle to depict the post-lapsarian World. Allusions to science come to us through the two dinosaurs disporting themselves in the distance. The dinosaur in the distance is Martin's symbol of scientific development: an animal whose very reconstitution asserted the achievement of science in 1824 carried out by Buckland. By 1824, Buckland who had found some pieces of ancient bones identified the organism as being a giant animal related to the Sauria (lizards). Paleontological restorations usually depict the struggle between predators and prey. The binary of predator and prey was enacted theatrically by Buckland in a lecture related by Henry Acland:

He lectured on the Cavern of Torquay, the now famous Kent's Cavern. He paced like a Franciscan Preacher up and down behind a long show-case, up two steps, in a room in the old Clarendon. He had in his hand a huge hyena's skull. He suddenly dashed down the stepsrushed, skull in hand, at the first undergraduate on the front benchand shouted, 'What rules the world?' The youth, terrified, threw himself against the next back seat, and answered not a word. He rushed then on me, pointing the hyena full in my face-' What rules the world?' 'Haven't an idea,' I said. 'The stomach, sir,' he cried (again mounting his rostrum), 'rules the world. The great ones eat the less, and the less the lesser still' (Gordon, 1970).

The Kirkdale cave hyenas made Buckland a scientific superstar. The concept of struggle was enacted in Buckland's lecture when he announced that the ruling principle in the world was stomach and the consequent competition for getting food. The discourse of struggle for existence which is as old as pre-historic animals, finds echo in Martin's use of dinosaurs in his paintings as giants in battle (Fig. 2). 
The world into which Martin's Adam and Eve are expelled is a desolate and lowering wilderness. Martin uses V shaped lines in this scene in order to strengthen the notion of void and exposure to a rough environment in which Adam and Eve are shelterless; these sharp angles and $\mathrm{V}$ shaped lines are in contrast to the $\mathrm{U}$ shaped lines of the paradise that seems to be protecting Adam and Eve in its round womb. The world of nature with its soft curves has been replaced with the world of technology with its harsh rugged lines. The dinosaurs, on the one hand, point to the potentials of science in the society in which humanity must live from now on, on the other hand, it points to the on-going struggle for existence. In Buckland's England, images of a violent prehistoric nature had to fight their way open due to the dominance of the first visualizations of extinct creatures shaped principally by the pictorial tradition of biblical illustration, which previously had pictured the antediluvian world in bucolic scenes reminding the viewer of the Garden of Eden (Semonin, 1997, p. 172). However, such pastoral views of prehistoric nature were radically altered by English artist John Martin, whose mezzotint The Country of the Iguanodon (Fig. 3) shows two dragon-like creatures engaged in mortal combat, "the peaceful, pastoral tone of so many earlier scenes has been abruptly replaced by the nightmarish 'Gothick' melodrama of the Martinesque style," observes paleontologist Rudwick (1992) in his Scenes from Deep Time, a study of the nineteenth-century pictorial traditions that attempts to visualize prehistoric nature (p. 80). The extinction of the dinosaurs, the animals that once ruled supreme, strengthens the notion of struggle for existence. Martin in this mezzotint emphasizes the battle between the dragons for, perhaps, "survival" which is a prefiguration of Darwin's Survival of the Fittest. In his Expulsion Scene (Fig. 2), he shows the primitive savage empire of dinosaurs in the prehistoric natural world only to highlight their dooming extinction by putting them in a hardly discernable position and therefore he denied them the powerful ruling position.

The only powerful figure in Martin's illustrations, the only one who is not overwhelmed by the environment, is Satan, and only after he builds Pandemonium. Martin chose to illustrate Satan when:

High on a throne of royal state, which far/Outshone the wealth or Ormus and of Ind, /Or where the gorgeous East with richest hand/Showers on her kings barbaric pearl and gold,/Satan exalted sat (Milton, 1667, Book 2, 1l. 1-5). 
Perhaps the source of this scene's appeal to Martin is the allusions to secular wealth and property that can be found in non-western societies such as "Ormus," "Ind," and "gourgous East" with the colonial echoes they have for the Britons. In order to have a deeper grasp of what was called the colonial discourse, Loomba (2000) draws on OED's definition of colony which is:

A settlement in a new country... a body of people who settle in a new locality, forming a community subject to or connected with their parent state; the community so formed, consisting of the original settlers and their descendants and successors, as long as the connection with the parent state is kept up (p.1).

She believes that this definition includes only the people that have taken hold of other people's lands and have formed a settlement there. No mention is made of the host country whose resources are being exploited by the colonizer (p. 1). This self-righteous denial of any textual space reflects the way the colonizer denied the colonized any geographical space. During the $19^{\text {th }}$ century an important motif in the works of the British writers was the stereotypical picture of the non-western other. The way Martin enacts this occupation is by rendering Hell as the uncivilized wild virginal area. In order to fertilize/civilize this virgin land, a "spacious wound" must be opened into it, so that it would become easy for the colonizers - Satan and the rebel angels - to establish such a kingdom in there that would outdo the "works of Memphian kings":

There stood a hill not far, whose grisly top /Belched fire and rolling smoke; the rest entire /Shone with a glossy scurf-- /undoubted sign That in his womb was hid metallic ore, /The work of sulphur. Thither, winged with speed, /A numerous brigade hastened: as when bands /Of pioneers, with spade and pickaxe armed, /Forerun the royal camp, to trench a field, /Or cast a rampart (Milton, 1667, Book 1, 11. 670-8).

Martin is inspired by this particular scene in which pioneers, by whom Milton meant sappers or engineers, rushed to make known whatever was unknown in the virgin land. This is the slogan announced by Sir William Jones (1784), the founder-president of Asiatic Researches, the Asiatic Society of Bengal: "You will investigate whatever is rare in the stupendous 
fabric of nature; will correct the geography of Asia by new observations..." (p. 355). Jones' words, like a manifesto, testify to the $19^{\text {th }}$ century notion of the "Civilizing Mission" which holds that the western rational scientific system should be spread throughout the irrational non-western world in order to establish civilizations in places whose resources would be otherwise wasted away.

Most appealing to Martin is that part of Milton's text where Satan's colonization of Hell is described by the epic voice, where bowels of mother Earth are rifled for treasures better hid, and where ribs of gold are dug out. Milton's comparison between the architects among Satan's crew and those of ancient eastern kings is also of interest to Martin because it justifies the superiority of the colonizers to those of the host countries.

As Lessing says, the painter cannot narrate a sequence of event but should choose the most pregnant moment to depict; therefore, Martin chooses the point when the imperialistic power of Satan reaches its acme; Martin, unlike William Blake, subtly chooses to preclude from his illustrations the degeneration of Satan. Martin feels no qualm in bestowing the position of power to Satan and never bothers to depict him in his degenerated state. Martin's Satan deserves the position due to his potentialities, that is his own and his crew's mastery of industry that allows them to ravish the virgin soil of Hell and to establish a civilization there. Martin is apt to depict tiny human figures, subjugated to the environment. Adam and Eve before and after expulsion, are subjugated to the overwhelming nature that surrounds them, the nature is either comprised of luxuriant greenery or rocky mountains. Even the deities are as tiny and as subjugated to the environment as Adam and Eve. In Raphael's Visit (Fig.4), Raphael appears in a small corner in a panorama of trees and mountains fading into horizon.

The only exception to this rule appears in Satan Exalted (Fig. 5) where Satan dominates the scene. Only when nature is totally harnessed, in this case removed, can anyone feel powerful. Satan is the agent of civilization that has managed to tame the chaos of the natural world and is therefore triumphant. Satan, exalted, dominates the scene; and the huge rotunda reminds one of the planet Earth captured and ruled by Satan, the colonizer/civilizer. John Martin, himself an engineer, has taken pains to perfectly observe mathematical and geometrical rules in his paintings that embody "a more detailed, more complicated, more original display of architecture than any previous work...characteristic of the Mechanical 
Sublime" (Svendsen, 1961, p. 65). In the composition of Satan's palace, Martin follows a style of diagrammatic drawing that emerged with the rapid development of technology and its aim was to exalt "the aesthetics of the machine" (Klingender, 1947, p. 61).

To reach the point Martin is trying to convey, perhaps one can look at the parts Martin has chosen to include and those he has excluded from his illustrations. Martin's use of architectural perspective and the mechanical sublime in Pandemonium expresses a nineteenth century style that could meet the requirements of Martin's time. This particular scene depicts the early $19^{\text {th }}$ century setting with its emphasis on technology as the center of civic life. The strong emphasis on the binary of civilization and wild nature does not appear in the works of other illustrators of Paradise Lost, who have visualized it in different ages. By taking a close look at Martin's selection of the scenes of the poem, one would notice Martin's abandonment of God the Father and the Son. Martin depicts only the reign of Satan, not that of God. In Satan Exalted, Satan, high above all, in his central position is greatly confidant of his power. He is the representation of the unshakeable secular wealth and power the possession of which was recommended in the utilitarian discourse. Satan's throne is situated at the top of a spherical space, similar to planet Earth. Proud of his scientifically built palace, he has dominated and colonized the whole Earth right in the middle of his Empire.

Martin, in his illustration of the enthronement of Satan puts emphasis on the intricate design of architecture as the symbol of Western civilization and Western pride. The subjugated position of the Earth in this painting shows the rightful power of Western civilization to tame the uncivilized natural world.

In Martin's Paradise Lost, the relation of the viewer to the subjecteven when a deity is there like the scene where Raphael is warning Adam and Eve - is that of an omniscient viewer, namely Adam, Eve, and the deity are easily spied upon by the viewer. The only scene where this omniscient viewpoint is challenged is the enthronement of Satan where the viewer cannot help but be alarmed by Satan's absolute power over the others.

\section{CONCLUSION}

Martin, in an age of science and industry, heroizes Satan, or, in fact, science, typified by Satan. He justifies the power of Satan by excluding the 
presence of God the Father and the Son from his set of mezzotints. Satan's power is ascribed to his technological advance and his triumphant gesture in his palace with its scientific architecture consolidating the British pride at the Western civilization. Satan's throne being situated on top of a spherethat symbolizes Earth - is the containment of the discourse of the civilizing mission to tame the savagery of those places where the Western civilization is "missing." Adam and Eve have to struggle for existence, a struggle that has been foreshadowed in the image of the deer chased by the lion. The extinct dinosaurs, once the emperors of the natural world, reinforce the discourse of the struggle for existence. In Martin's illustrations, the only way to win the struggle seems to be through the achievements of science and technology. The only powerful figure, the only one sure to survive, is Satan who has managed to totally tame and remove the tumultuous, gothic nature. Martin, living at a time when creatures had to struggle for existence, was interested in the achievements of science and the establishment of civilization as the means of survival. Satan has accomplished to colonize Hell and is going to colonize the whole world with his scientific and industrial achievements; therefore, he is triumphant.

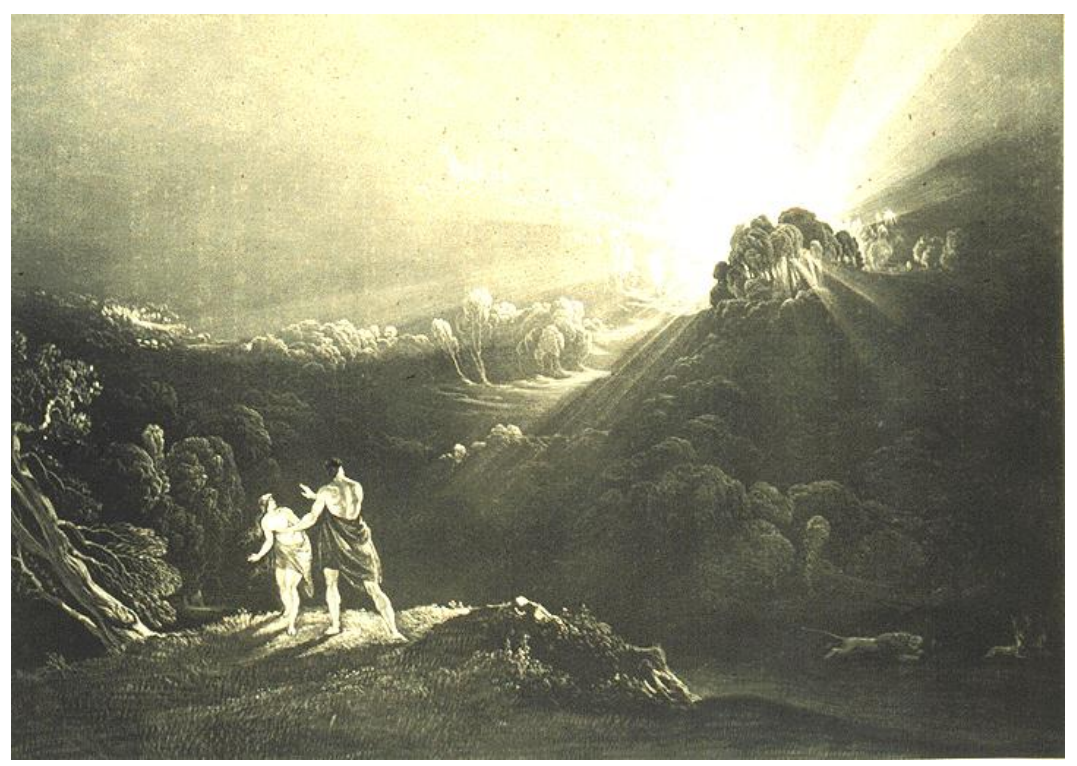

Fig. 1. John Martin. Adam and Eve Leaving Eden 


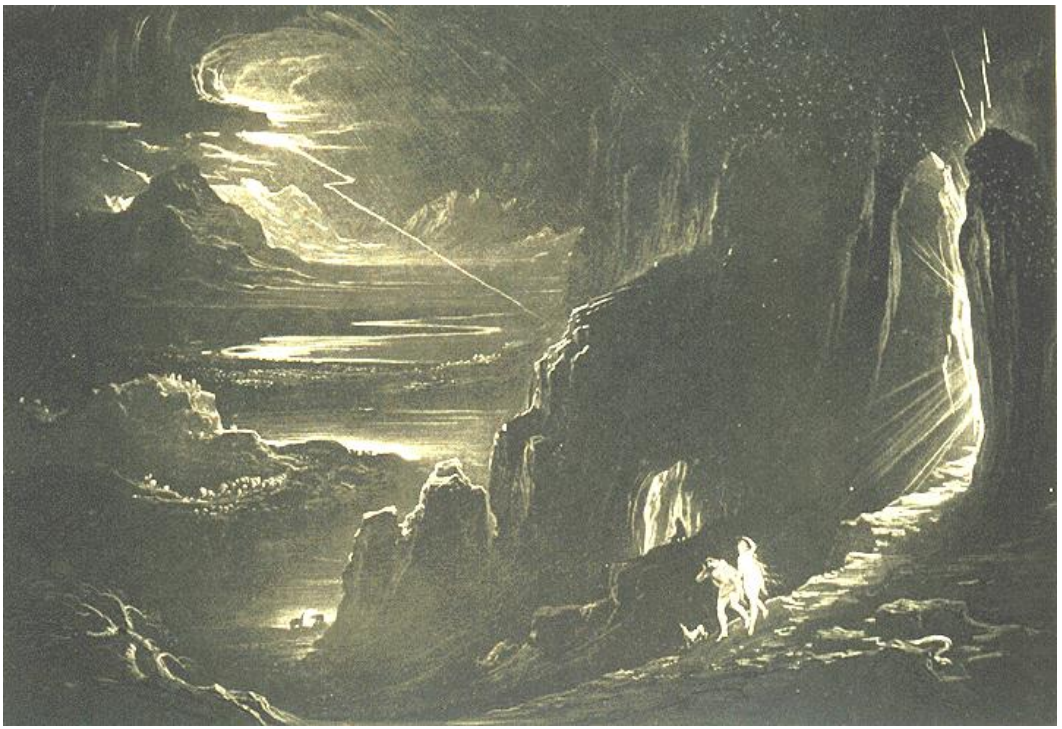

Fig. 2. John Martin, Expulsion of Adam and Eve

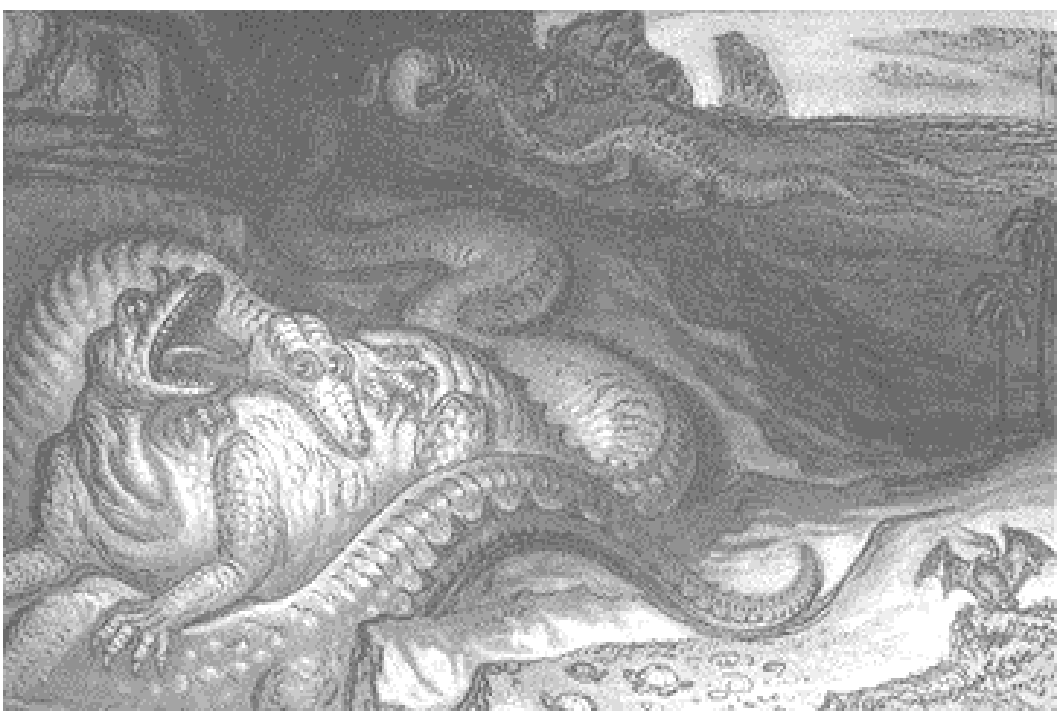

Fig. 3. John Martin, The Country of Iguanodon 


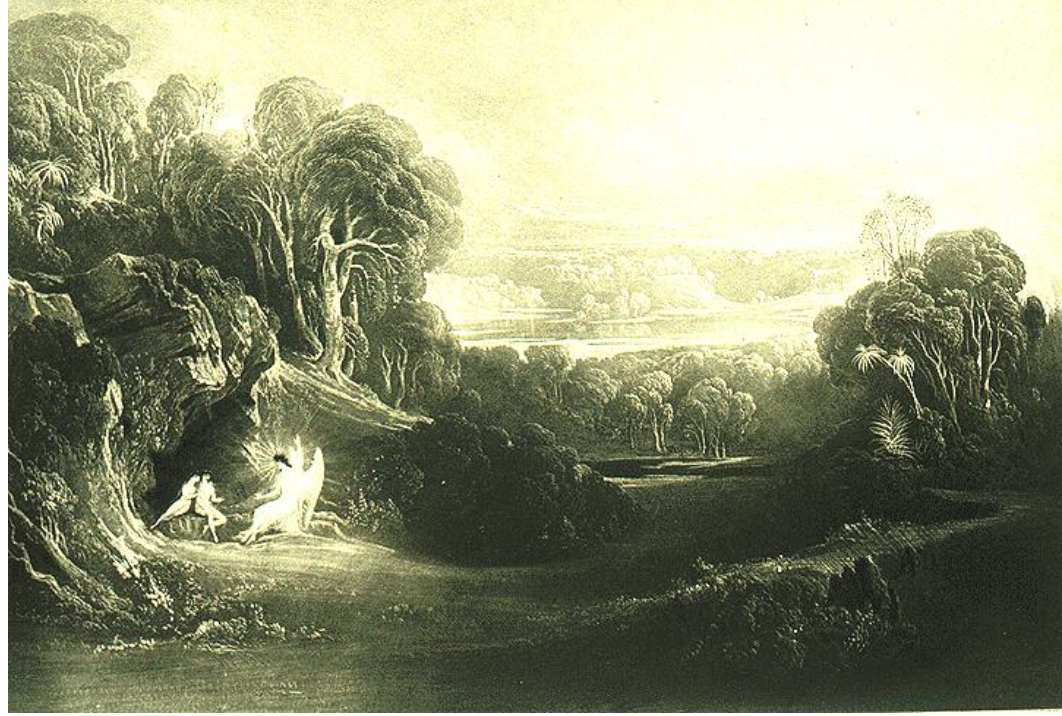

Fig. 4. John Martin, Raphael Conversing with Adam and Eve

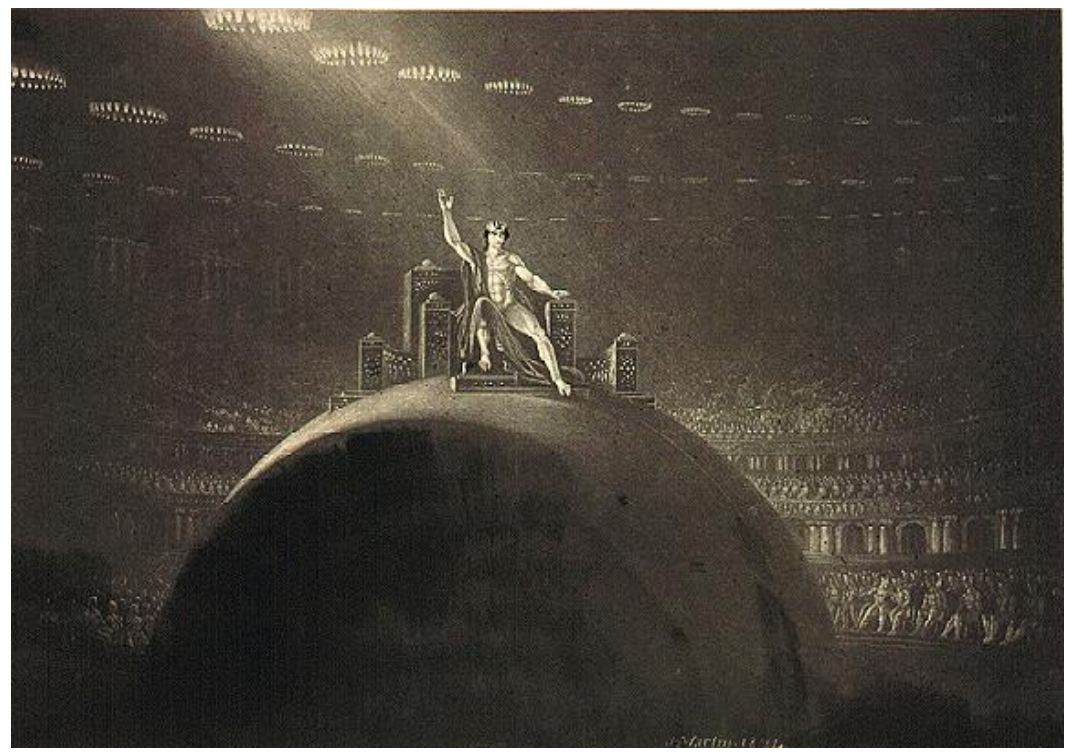

Fig. 5. John Martin, Satan Exalted 


\section{REFERENCES}

Adams, M. (2006). John Martin and the Prometheans. History Today, 56, $40-47$.

Adas, M. (1989). Machines as the measure of men: Science, technology, and ideologies of western dominance. Ithaca: Cornell University Press.

Barker, C. (2003). Cultural studies: Theory and practice. London: Sage.

Barlow, N. (Ed.). (1958). The autobiography of Charles Darwin 1809-1882. London: Collins.

Belsey, C. (1980). Critical practice. London: Methuen.

Bentham, J. (1781). Human dispositions in general. In An introduction to the principles of morals and legistlation (pp. 105-120). Kitchener: Batoche Books.

Bowler, P J. (1976). Malthus, Darwin, and the concept of struggle. Journal of the History of Ideas, 37, 631-650.

Davy, H. (1802). Discourse, introductory to a course of lectures on chemistry. In Laura Otis (Ed.), Literature and Science in the Nineteenth Century: An Anthology (pp.140-144). Oxford: Oxford University Press 2002.

Davy, J. (Ed.) (1840). The collected works of Sir Humphry Davy. (Vol. 8). London: Smith, Elder and Co.

Foote, G. A. (1954). Science and its function in early nineteenth century England. Osiris, 11, pp. 438-454.

Gaither, M. (1971). Literature and the arts. In Stallknecht \& Horsd Frenz (Eds.), Comparative literature, method and perspective (pp.153-172). Carbondale: Southern Illinois University Press.

Gordon, E.O. (1970). The Life and Correspondence of William Buckland, D.D., F.R.S. London: Murray. Retrieved March 20, 2011 from http://www. ebooksread.com/authors-eng/elizabeth-oke-buckland-gordon/thelife-and-correspondence-of-william-buckland-ddfrs-sometime-deanof-w-hci/page-3-the-life-and-correspondence-of-william-bucklandddfrs-sometime-dean-of-w-hci.shtml.

Jones, W. (1784). A discourse on the institution of a society. The Monthly Review, 71, 354-379.

Klingender, F.D. (1974). Art and the industrial revolution. London: Noel Carrington.

Loomba, A. (2000). Colonialism/Postcolonialism. London: Routledge.

Martin, J. (1824-26). Adam and Eve leaving. Retrieved August 18, 2011, from http://myweb.stedwards.edu/georgek/milton/martin/martin23.html.

Martin, J. (1824-26). Raphael conversing with Adam and Eve. Retrieved August 18, 2011, from http://www.spaightwoodgalleries.com/Pages/Martin3.html.

Martin, J. (1824-26). Satan exalted. Retrieved August 18, 2011, from http://myweb.stedwards.edu/georgek/milton/martin/martin5.html. 
Martin, J. (1837). The Country of guanodon. Retrieved August 18, 2011, from http://collections.tepapa.govt.nz/objectdetails.aspx?oid=229590.

Martin, J. (1824-26). Expulsion of Adam and Eve. Retrieved August 18, 2011, from http://myweb.stedwards.edu/georgek/milton/martin/martin24.html.

Milton, J. (1667). Book one. In M. Y. Hughes (Ed.), Paradise Lost (LL 670-8). New York: The Odyssey Press.

Milton, J. (1667). Book two. In M. Y. Hughes. (Ed.), Paradise Lost (LL 1-5). New York: The Odyssey Press.

Nikolajeva, M. \& Scott, C. (2000). The Dynamics of picturebook communication. Children's Literature in Education, 31, 225-239.

Rudwick, M. J.S. (1992). Scenes from deep time: Early pictorial representation of the prehistoric world. Chicago, IL: Univ. of Chicago Press.

Semonin, P. (1997). Empire and extinction: The dinosaur as a metaphor for dominance in prehistoric nature. Leonardo, 30, 171-182.

Svendsen, K. (1961). John Martin and the expulsion scene of Paradise Lost. Studies in English Literature, 1, 63-73.

Tyson, L. (2006). Critical theory today, $2^{\text {nd }}$ ed. New York: Routledge.

Wolf, B. J. (1985). A Grammar of the sublime, or intertextuality triumphant in Church, Turner, and Cole, New Literary History, 16, 321-41. 